\title{
Implementasi Nilai-Nilai Karakter dan Keteladanan K.H Ahmad Dahlan pada Siswa Usia 6-8 Tahun
}

\author{
Nana Sutarna1, Nika Cahyati ${ }^{\circledR}$, Tio Heriyana ${ }^{3}$, Delia Anggraeni ${ }^{1}$, Indri Ayu Lestari ${ }^{1}$ \\ Pendidikan Guru Sekolah Dasar, STKIP Muhammadiyah Kuningan, Indonesia(1); Pendidikan \\ Guru Pendidikan Anak Usia Dini, STKIP Muhammadiyah Kuningan, Indonesia(2) ; \\ Pendidikan Matematika, STKIP Muhammadiyah Kuningan, Indonesia(3) \\ DOI: $\underline{10.31004 / o b s e s i . v 6 i 4.2167}$
}

\begin{abstract}
Abstrak
Tujuan penelitian ini agar dapat mengetahui nilai karakter dan keteladanan yang diajarkan oleh K.H. Ahmad Dahlan pada anak usia 6-8 tahun di SD Aisiyah Kabupaten Kuningan. Metode penelitian ini adalah menggunakan metode penelitian kualitatif dengan jenis penelitian kualitatif deskriptif, subjek penelitian ini adalah pada siswa SD usia 6-8 Tahun sebanyak 18 siswa di SD Aisiyah Kabupaten Kuningan. Teknik pengumpulan data menggunakan teknik observasi, wawancara dan dokumentasi. Hasil Penelitian ini menunjukan bahwa terdapat beberapa nilai-nilai karakter K.H Amad Dahlan yang di tanamkan, hasil penelitian menunjukan terdapat 4 nilai karakter dan keteladanan yang ditanamkan pada anak usia 6-8 Tahun oleh SD Aisiyah Kabupaten Kuningan, yaitu nilai religius, nasionalis, Jujur dan integritas, pendidikan karakter yang di tanamkan di SD Aisiyah Kabupaten Kuningan menanamkan pendidikan karakter sesuai dengan ajaran K.H. Ahmad Dahlan.
\end{abstract}

Kata Kunci: Karakter; keteladanan; K.H. Ahmad Dahlan; Anak Usia Dini

\begin{abstract}
The purpose of this research is to know the value of character and example taught by K.H. Ahmad Dahlan in children aged 6-8 years at Aisiyah Elementary School, Kuningan Regency. This research method is using qualitative research methods with descriptive qualitative research type, the subject of this research is elementary school students aged 6-8 years as many as 18 students at Aisiyah Elementary School, Kuningan Regency. Data collection techniques using observation techniques, interviews and documentation. The results of this study indicate that there are several character values of KH Amad Dahlan that are instilled, the results of the study show that there are 4 character and exemplary values that are instilled in children aged 6-8 years by SD Aisiyah, Kuningan Regency, namely religious, nationalist, honest and integrity, Character education instilled in SD Aisiyah, Kuningan Regency instills character education in accordance with the teachings of K.H. Ahmad Dahlan.
\end{abstract}

Keywords: Character; exemplary; K.H. Ahmad Dahlan; Early childhood

Copyright (c) 2022 Nana Sutarna, et al.

$\triangle$ Corresponding author:

Email Address : nika@upmk.ac.id (Kuningan, Indonesia)

Received 26 October 2021, Accepted 10 January 2022, Published 20 January 2022 


\section{PENDAHULUAN}

Pendidikan dapat menjadi tolok ukur bagi kemajuan dan kualitas suatu bangsa, sehingga dapat dikatakan bahwa kemajuan suatu negara dapat dicapai salah satunya dengan pembaharuan dan penataan pendidikan yang baik. Jadi pendidikan mempunyai peran penting dalam menciptakan masyarakat yang cerdas, pandai, berilmu pengetahuan yang luas, berjiwa demokratis serta berakhlaqul karimah. Penanaman karakter siswa melalui keteladanan dan ketokohan mampu menjadikan berkepribadian yang baik dan berguna dalam kehidupan sehari-hari mulai dari lingkungan sekolah, keluarga, dan masyarakat, Seperti halnya dicontohkan oleh tokoh Pahlawan Nasional yang bergerak dalam bidang keagamaan yaitu KH. Ahmad Dahlan. KH. Ahmad Dahlan mempunyai peran penting dalam sejarah Indonesia khususnya pada masa pergerakan nasional. Beliau mendirikan organisasi Muhammadiyah sekaligus meluruskan agama islam yang pada masa itu masyarakat Indonesia masih percaya dengan pemikiran yang telah diwarisi oleh nenek moyangnya. Hal tersebut tetap berkembang kemudian muncul adat istiadat yang menjadi pegangan hidup pada masa itu. Anak memiliki jiwa sosial learning atau anak meniru berdasarkan lingkungan sekitar(Haerudin, 2018) , keteladanan tokoh dapat menjadikan contoh bagi anak untuk bisa meniru atau meneladani perilaku tokoh tersebut, $\mathrm{KH}$. Ahmad Dahlan Memiliki keteladanan mandiri, mencintai ilmu pengetahuan, jiwa wirausaha, pandai berorganisasi, nasionalisme, cerdas, dan tidak pernah membeda-bedakan. Hal ini dapat menjadikan sebuah keteladanan bagi siswa, sehingga keteladanan KH. Ahmad Dahlan dapat ditiru dan dapat diimplementasikan dengan membiasakan siswa melakukan hal tersebut, sehingga keteladanan KH. Ahmad Dahlan dapat menjadi contoh bagi semua insan termasuk diantaranya siswa usia sekolah dasar.

KH Ahmad Dahlan senantiasa memikirkan anak-anak generasi dimasa yang akan datang supaya selalu dapat menjadi generasi Islam yang memiliki nilai juang yang tinggi terhadap Islam. Untuk itu di tengah-tengah sakitnya yang semakin parah diawal tahun 1923, KH Ahmad Dahlan memberikan beberapa nasehat dan wasiat. Dalam nasehat dan wasiat tersebut terdapat pembahasan mengenai pendidikan karakter yang sudah mulai mengalami kemerosotan, nasehat dan wasiat itu ialah sebagai berikut, kemunduran umat sebagian besar pemeluk islam sudah terlalu jauh meninggalkan ajaran Islam yang membuat Islam mengalami kemunduran. Kemunduran Islam tersebut disebabkan kemerosotan akhlak sehingga mengalami penuh ketakutan dan tidak memiliki keberanian. Melihat keadaan yang demikian KH Ahmad Dahlan pun berwasiat, "karena itu aku terus memperbanyak amal dan berjuang bersama anak-anakku sekalian untuk menegakkan akhlak dan moral yang sudah mulai bengkok"(Ahmad Dahlan, 1985).

Pendidikan keteladanan menjadi alternatif dalam kaitannya dengan penguatan pendidikan karakter. Proses penerapan pembelajaran pendidikan keteladanan untuk siswa akan menjadi pusat dan tema utama dalam dunia pendidikan di Indonesia. Pemerintah Indonesia menekankan penanaman nilai-nilai karakter dan keteladanan yang tidak hanya diterapkan di keluarga saja tetapi mulai diajarkan sejak awal dari taman kanak-kanak (kindergarten) hingga pendidikan tinggi. Penanaman nilai-nilai karakter menjadi sasaran penting di proses pembelajaran di sekolah dasar.

Keteladanan mengenai penanaman pendidikan karakter bagi anak masi kurang, perlunya menelaah kembali konsep pendidikan karakter yang diajarkan para tokoh di masa lalu, seperti K.H. Ahmad Dahlan yang dapat menjadi teladan, serta perlunya pengembangan metode penanaman karakter pada anak agar dapat sesuai dengan perkembangan zaman. Maka penelitian ini membatasi pada nilai karakter apa saja yang diajarkan oleh K.H Ahmad Dahlan yang menjadi sumber teladan, serta bagaimana mengimplementasikan nilai-nilai dan keteladanan pada siswa usia 6-8 tahun di SD Aisiyah di Kabupaten Kuningan. Tujuan penelitian ini adalah untuk mengetahui nilai-nilai karakter yang diajarkan oleh KH. Ahmad Dahlan yang menjadi sumber teladan, serta untuk mengetahui pengimplentasian nilai-nilai 
karakter dan keteladanan KH. Ahmad Dahlan pada siswa usia 6-8 tahun di Kabupaten Kuningan.

Pada umumnya metode yang digunakan hanya dalam bentuk pembelajaran secara konvensional, sehingga penanaman tidak terfokus pada satu arah, namun dengan menggunakan penokohan, hal ini dapat mendukung sebuah penanaman karakter bagi siswa, karena siswa memerlukan model atau contoh nyata bagi dirinya, agar siswa dapat meniru contoh yang baik agar dapat diimplementasikan dalam dirinya. Seperti dalam teori(Albert, 1977) mengenai social learning yaitu bahwa seseorang anak belajar melalui lingkungan sosialnya, atau melalui contoh. Maka hal ini mendukung bahwa sebuah tokoh dapat menginspirasi bagi siswa dalam penanaman karakter. K.H. Ahmad Dahlan merupakan tipe man of action sehingga sudah pada tempatnya apabila mewariskan cukup banyak amal usaha. Oleh sebab itu untuk menelusuri bagaimana konsep pendidikan karakter Ahmad Dahlan mestinya lebih banyak merujuk pada bagaimana ia membangun sistem pendidikan. Dengan usaha beliau di bidang pendidikan, Ahmad Dahlan dapat dikatakan sebagai suatu model dari bangkitnya sebuah generasi untuk menjawab tantangan-tantangan yang dihadapi Islam yaitu, ketertinggalan umat Islam di bidang pendidikan.

K.H. Ahmad Dahlan senantiasa memikirkan anak-anak generasi di masa yang akan datang supaya selalu dapat menjadi generasi Islam yang memiliki nilai juang yang tinggi terhadap Islam. Untuk itu di tengah-tengah sakitnya yang semakin parah diawal tahun 1923, K.H. Ahmad Dahlan memberikan beberapa nasehat dan wasiat. Dalam nasehat dan wasiat tersebut terdapat pembahasan mengenai pendidikan karakter yang sudah mulai mengalami kemerosotan, nasehat dan wasiat itu ialah sebagai berikut, kemunduran umat sebagian besar pemeluk islam sudah terlalu jauh meninggalkan ajaran Islam yang membuat Islam mengalami kemunduran. Kemunduran Islam tersebut disebabkan kemerosotan akhlak sehingga mengalami penuh ketakutan dan tidak memiliki keberanian. Melihat keadaan yang demikian K.H. Ahmad Dahlan pun berwasiat, "karena itu aku terus memperbanyak amal dan berjuang bersama anak-anakku sekalian untuk menegakkan akhlak dan moral yang sudah mulai bengkok". Konteks pendidikan karakter KH. Ahmad Dahlan, pendidikan hendaknya diarahkan pada usaha membentuk manusia muslim yang berbudi pekerti luhur, luas pandangan dan paham masalah ilmu keduniaan serta bersedia berjuang untuk kemajuan masyarakat (Wiranata, 2019).

Sewaktu kecil, Muhammad Darwis bergaul akrab dengan kawan-kawan tetangganya. Beliau dikenal sebagai anak yang rajin, jujur, dan suka menolong, serta mempunyai kelebihan yaitu pandai membuat kerajinan tangan dan membuat barang-barang permainan.Oleh sebab itu tidak mengherankan bila Muhammad Darwis disayangi oleh teman-teman sepermainan dan sekampungnya (Ahmad Dahlan, 1985). Di usia remaja ia juga sudah menunjukkan sikap dan berbagai keunggulan dibanding teman-teman sebayanya. Terutama dalam kecermatan dan kehati-hatiannya dalam menghadapi persoalan, saat mengambil keputusan dan bertindak. Kemampuan akal pikirannya dikembangkan secara maksimal, sehingga kecerdasan kedinamisan serta kreatifitas Dahlan kecil sudah Nampak (Sutarna \& Anwar, 2020).

Dalam menyampaikan keteladanan kepada anak didik ada dua cara dalam penyampaiannya, pertama secara langsung, pendidik menyampaikan atau mencontohkan kepada anak berupa sikap, perbuatan, perkataan yang menjadi nilai sebagai motivasi untuk belajar anak, kedua secara tidak langsung pendidik menyampaikan kisah atau cerita-cerita tentang seseorang yang jujur, adil, bijaksana, berkerja keras dan pantang menyerah serta mandiri dalam melakukan dan memperoleh sesuatu yang akan dicapai. Pendidikan yang diselenggarakan oleh K.H. Ahmad Dahlan tidak hanya bertujuan untuk mencerdaskan umat muslim secara intelektual saja, melainkan juga berupaya untuk mengembangkan kepribadiannya. Seorang muslim yang maju secara intelektual, sekaligus memahami dan memegang teguh ajaran agamanya, serta mengamalkan segala perintah agama merupakan tujuan akhir dari pendidikan yang diusahakannya. Hasil akhir yang didambakannya dari 
pendidikan tadi adalah terbentuknya masyarakat yang sejahtera, damai, serta terbebas dari segala kungkungan, termasuk kungkungan kolonialisme Barat (Kumalasari, 2017).

Keteladanan juga dapat ditunjukkan dalam perilaku dan sikap pendidik dan tenaga kependidikan dalam memberikan contoh tindakan-tindakan yang baik berupa nilai-nilai yang positif seperti tingkah laku, sifat, cara berpikir, dan sebagainya. sehingga diharapkan menjadi panutan bagi peserta didik untuk mencontohnya (Puspitasari, 2014). Menerapkan keteladanan di sekolah, ada beberapa hal yang dapat digunakan antara lain: 1) Memberikan keteladanan dengan cara yang dapat dilihat anak. 2) Keteladanan bisa dilakukan dalam proses pembelajaran di kelas melalui cerita. 3) Keteladanan juga dapat diterapkan dengan cara guru atau pendidik memberikan contoh pada anak dengan cara merespon orang-orang yang membutuhkan di sekitar (Hadisi, 2015). Berdasarkan dari beberapa pendapat diatas peneliti dapat menyimpulkan bahwa keteladanan adalah suatu aspek perilaku dalam bentuk tindakan yang nyata, serta mengandung unsur ilustrasi dalam penerapannya. Teori social learning dari (Albert, 1977) mengatakan bahwa anak belajar dari lingkungannya, sehingga memberikan keteladanan pada siswa dengan memberikan contoh keteladanan dari K.H Ahmad Dahlan merupakan salah satu altternatif agar siswa dapat termotivasi mengimplementasikan keteladanan dalam hidupnya. Ternyata bagi siswa melihat keteladanan secara langsung dapat lebih menyerap secara maksimal, dibandingkan hanya dengan bercakap-cakap mengenai keteladanan. Keteladanan merupakan salah satu hal yang penting dalam pendidikan. Pembiasaan dan keteladanan merupakan proses pendidikan yang berlangsung dengan membiasakan dan mencontohkan perilaku atau sosok figur dalam bertingkah laku, berbicara, berpikir dan melakukan aktivitas tertentu untuk membentuk kebiasaan yang baik sehingga akan membentuk karakter yang baik pula (Budiyono \& Harmawati, 2020). Keteladanan dalam pendidikan adalah cara mendidik dan memberi contoh dimana anak dapat menirunya baik dari segi perkataan, perbuatan, maupun cara berfikir. Salah satu faktor yang mempunyai pengaruh terhadap pendidikan dan dalam kehidupan manusia sehari-hari adalah uswatun hasanah atau suri teladan.

Silvie Mil (2018) dengan judul “Penanaman Nilai-Nilai Kemuhammadiyahan sebagai Penguatan Pendidikan Karakter Sejak Dini di TK Aisyiyah Bustanul Athfal 24 Kayu Putih, Jakarta Timur", dan ketiga adalah Ratnasari Diah Utami (2015) dengan judul "Membangun Karakter Siswa Pendidikan Dasar Muhammadiyah Melalui Identifikasi Implementasi Pendidikan Karakter di Sekolah". Penelitian tersebut membahas tentang pendidikan karakter dalam lingkup Muhammadiyah, namun fokus penelitiannya membahas implementasi pendidikan karakter, Dalam rangka menuju cita-cita pendidikan yang berkarakter, peneliti mencoba mengurai pemikiran yang pernah ditawarkan oleh tokoh pembaharuan, $\mathrm{KH}$ Ahmad Dahlan, hal ini dimaksudkan untuk mencoba mencari solusi terhadap problematika pendidikan di Indonesia saat ini.

KH Ahmad Dahlan merupakan tipe man of action sehingga sudah pada tempatnya apabila mewariskan cukup banyak amal usaha. Oleh sebab itu untuk menelusuri bagaimana konsep pendidikan karakter Ahmad Dahlan mestinya lebih banyak merujuk pada bagaimana ia membangun sistem pendidikan. Dengan usaha beliau di bidang pendidikan, Ahmad Dahlan dapat dikatakan sebagai suatu model dari bangkitnya sebuah generasi untuk menjawab tantangan-tantangan yang dihadapi Islam yaitu, ketertinggalan umat Islam di bidang pendidikan.

\section{METODOLOGI}

Penelitian ini menggunakan metode kualitatif deskriptif. Jenis penelitian deskriptif kualitatif merupakan sebuah metode penelitian yang memanfaatkan data kualitatif dan dijabarkan secara deskriptif.

Jenis penelitian ini juga mempunyai tujuan untuk menyajikan gambaran lengkap mengenai setting sosial atau dimaksudkan unntuk eksplorasi dan klarifikasi mengenai suatu fenomena atau kenyataan sosial dengan cara mendeskripsikan sejumlah variabel yang 
berkenaan dengan masalah dan unit yang diteliti antara fenomena yang diuji. Ditinjau dari jenis data maka penelitian yang digunakan adalah penelitian kualitatif melalui pendekatan deskriptif. Jenis penelitian deskriptif kualitatif yang digunakan dalam penelitian ini untuk menuturkan pemecahan masalah yang ada berdasarkan data-data. Penelitian deskriptif kualitatif ini untuk memperoleh informasi dan hasil dari penanaman nilai-nilai karakter K.H Ahmad Dahlan di SD Aisiyah Kabupaten Kuningan.

Sumber data dalam penelitian ini adalah terdiri dari pendidik, tenaga kependidikan dan anak usia 6-8 tahun sebanyak 18 anak, penelitian ini berada pada SD Aisiyah di Kabupaten Kuningan. Prosedur penelitian ini adalah mengamati secara langsung karakter yang ditanamkan, melihat pembiasaan yang dilakukan sehari-hari pada anak usia 6-8 tahun pada siswa SD Aisiyah sebanyak 18 anak, walaupun kegiatan pembelajaran dilakukan secara terbatas, namun pembiasaan tetap dilaksanakan.

Teknik pengumpulan data menggunakan observasi atau pengamatan terhadap karakter siswa sebelum penanaman nilai karakter KH. Ahmad Dahlan dan setelah penanaman nilai karakter KH. Ahmad Dahlan. Wawancara kepada guru untuk mengetahui perubahan sikap dari siswa setelah dilakukannya penanaman nilai karakter, selain itu pengumpulan data menggunakan teknik dokumentasi berupa melalui kurikulum yang di gunakan di SD Aisiyah Kabupaten Kuningan. Instrumen yang digunakan adalah human instrumen atau peneliti sendiri yang berfungsi menetapkan fokus penelitian, memilih informan sumber data, pengumpulan data dan analisis data serta melakukan kesimpulan. Instrumen lainnya adalah pedoman wawancara dan juga lembar observasi, wawancara dilakukan secara langgsung pada pendidik serta kepada tenaga kependidikan dengan memenuhi standar protokol kesehatan. Data yang terkumpul dari wawancara, analisis dokumen dan observasi dilakukan melalui proses identifikasi, analisis dan penyimpulan. Langkah penelitian diilustrasikan dengan tabel 1.

Tabel 1. Langkah-langkah penelitian (Creswell, 2010)

\begin{tabular}{|c|c|c|c|}
\hline Pengumpulan data & Reduksi data & Penyajian data & Penarikan kesimpulan \\
\hline Menyusun instrumen & $\begin{array}{l}\text { Mengelompokkan } \\
\text { hasil wawancara dan } \\
\text { hasil observasi }\end{array}$ & $\begin{array}{l}\text { Menyusun } \\
\text { pengelompokan } \\
\text { wawancara dan } \\
\text { observasi dengan } \\
\text { beberapa sumber yang } \\
\text { di narasikan }\end{array}$ & Penarikan kesimpulan \\
\hline $\begin{array}{l}\text { Mencari referensi dari } \\
\text { berbagai sumber } \\
\text { Melakukan } \\
\text { wawancara mendalam } \\
\text { dengan responden }\end{array}$ & $\begin{array}{l}\text { Uji kredibilitas dan } \\
\text { triangulasi sumber }\end{array}$ & & \\
\hline
\end{tabular}

\section{HASIL DAN PEMBAHASAN}

\section{Implementasi nilai-nilai karakter dan keteladanan K.H. Ahmad Dahlan}

Tolok ukur keberhasilan suatu bangsa adalah dari keberhasilan generasi mudanya di masa yang akan datang, karena mempertahankan keberhasilan itu lebih sulit dari pada mendapatkannya. Salah satu faktor yang mempengaruhi keberhasilan tersebut adalah dari karakter bangsa itu sendiri. Pada zaman sekarang pembentukan karakter generasi muda ini menjadi tantangan tersendiri, seperti yang kita ketahui bersama bahwa globalisasi dan modernisasi ternyata sedikit banyaknya telah menggerus bahkan telah mematikan nilai - nilai karakter positif dari generasi muda bangsa ini. Maka dari itu pentingnya diterapkan pendidikan karakter sejak dini. 
Karakter merupakan salah satu nilai yang paling mendasar yang membentuk jati diri seseorang yang kemudian diwujudkan melalui sikap dan tingkah laku dalam kehidupan sehari - hari (Apriliyanti et al., 2021). Kemampuan seseorang dalam bermasyarakat tergantung dari karakter yang dimilikinya, karena itu karakter tidak akan lepas dari nilai dan norma yang berlaku dilingkungan masyarakat. Pendidikan dan karakter ini memiliki irisan yang sangat besar karena keduanya saling berkaitan. Esensi dari pendidikan ini harus memiliki karakter didalamnya. Akan tetapi pada saat ini esensi tersebut kurang dirasakan karena pendidikan saat ini lebih mengedepankan hasil bagaimana seorang anak harus mendapatkan nilai akademik yang besar. Pendidikan karakter merupakan kolaborasi dari orang tua, guru dan masyarakat (Prasanti \& Fitrianti, 2018).

Pemerintah melalui beberapa rancangan konsep kurikulumnya selalu menitik beratkan pada penerapan pendidikan karakter. Namun, yang sering kita lihat penerapan pendidikan karakter di lembaga pendidikan sebagian besar hanya sebatas implementasi belum pada tahap pengaplikasian. Pendidikan karakter ini tidak hanya teori - teori yang disampaikan disekolah melalui serangkaian kegiatan belajar mengajar saja, tetapi lebih kepada pembiasaan penerapan nilai - nilai keagamaan, disiplin, jujur, toleran, kerjasama, tanggungjawab dan sebagainya.

Muhammadiyah sebagai organisasi yang concern dalam bidang pendidikan serta berperan dalam membina generasi muda menjadikan pemuda - pemuda yang siap menghadapi segala tantangan di era globalisasi dan modernisasi ini, melalui berbagai program - program pembinaanya agar memiliki karakter bangsa yang menjunjung tinggi ajaran islam. Pembelajaran kemuhammadiyahan memberikan pemahaman kepada siswa tentang ideologi, keimanan dan karakter yang baik berlandaskan Al-Qur'an dan As-sunnah. Pembelajaran berbasis kemuhammadiyahan berorientasi pada setiap kegiatan pembelajaran yang dimulai dari awal siswa mulai masuk kelas sampai dengan siswa pulang sekolah(Ahmad Dahlan, 1985).

Muhammadiyah didirikan pada saat kondisi pendidikan pemerintah kolonial yang diskriminatif dan kondisi pendidikan islam yang memprihatinkan. Hal tersebut yang mendorong $\mathrm{KH}$ Ahmad Dahlan untuk menyelenggarakan sekolah Muhammadiyah yang memadukan pengetahuan umum dan pengajaran agama. Konsep ini diterapkan agar terjadi keseimbangan antara kecerdasan intelektual dan kecerdasan spiritual pada siswa. Ajaran islam merupakan dasar dari pendidikan karakter KH Ahmad Dahlan yang diantaranya yaitu Ilmu, Iman dan Amal. Pada prinsipnya agama bukan hanya sekedar pengetahuan saja, tetapi harus sampai amalan. Menurut Syafi'i Ma'arif, konsep pendidikan karakter KH. Ahmad Dahlan adalah menumbuhkan pribadi - pribadi yang cerdas namun tetap takut kepada Allah (Mulkhan, 2016). Menurutnya, semakin banyak ilmu yang dia peroleh, semakin membuatnya bertakwa kepada yang memberikan ilmu.

SD Aisyiyah Kuningan merupakan salah satu AUM dalam bidang pendidikan. SD Aisyiyah Kuningan dalam aktivitas kesehariannya selalu menerapkan nilai - nilai karakter dan keteladanan $\mathrm{KH}$. Ahmad Dahlan yang dimana tidak hanya mencerdaskan secara intelektual, akan tetapi juga membangun integritas dan kepribadian siswanya (HM Masrudin Anshory, 2010). Konsep yang dibentuk yaitu memadukan pendidikan akhlak dan pendidikan budi pekerti. Konsep ini menjadi sebuah alternatif untuk menemukan sebuah konsep pendidikan karakter yang ideal. Penelitian ini di fokuskan pada anak SD Aisiyah usia 6-8 tahun atau dengan anak kelas 1 dan 2 SD di Aisiyah Kabupaten kuningan. Alasannya karena penanaman karakter yang baik sejak dini akan menghasilakan karakter yang baik pula untuk anak dimasa mendatang.

Beberapa bentuk pembiasaan yang dilakukan di SD Aisyiyah Kuningan diantaranya yaitu di pagi hari pada saat masuk pukul 07.30 siswa dibiasakan untuk melaksanakan shalat dhuha berjamaah sebelum pembelajaran dimulai, dimana imam dipilih dari siswa secara bergantian setiap harinya dan dibimbing oleh guru. Setelah shalat dhuha siswa bermusyafahah dengan sesama teman dan guru secara tertib, hal ini dilakukan untuk menjaga 
silaturahmi diantara sesamanya. Kemudian dilanjutkan dengan Tahsin membaca Al-Qur'an, siswa dikelompokkan sesuai dengan jilid atau kemampuan siswa dalam mengaji. Tahsin ini diawali dengan tes mengaji siswa satu persatu secara acak. Ada tolok ukur yang menjadikan siswa bisa tidaknya melanjutkan ke halaman berikutnya.

Berdasarkan hasil wawancara bahwa SD Aisiyah di Kabupaten Kuningan bahwa mereka menggunakan kurikulum 2013 dengan muatan lokal, muatan lokal muatan lokal ini memuat mata pelajaran Sejarah Kebudayaan Islam, Bahasa Arab, Tahsin, dan Tahfidz. SD Aisyiyah juga menggunakan buku dari PP Muhammadiyah untuk dijadikan sebagai sumber belajar, ini yang membuat SD Aisyiyah berbeda dengan SD pada umumnya, fokus pendidikan karakter di SD muhammadiyah adalah berdasarkan karakter yang diterapkan oleh K.H. Ahmad Dahlan, dan di SD tersebut menerapkan program yang bernama The Nine Golden Habits yaitu Sholat dengan tertib, berpuasa sunah, berinfaq, beradab islami, membaca AlQur'an, membaca, menghadiri pengajian, berorganisasi, berfikir positif (Ahmad Dahlan, 1985). Dimana The Nine Golden habits ini diimplementasikan melalui kegiatan-kegiatan siswa, diantaranya seperti mengaji, sholat berjamaah, kepemimpinan, literasi. The Nine Golden Habits ini sudah terlaksana di implementasikan Pendidikan karakter yang dibina di SD Aisyiyah seperti kesederhanaan, kejujuran, tolong menolong, kerjasama. Pendidikan karakter tersebut diajarkan dengan implementasi langsung dan guru dijadikan sebagai panutannya, hal ini terlihat dalam kegiatan sehari-hari anak dalam pembiasaan di sekolah.

Kegiatan tersebut merupakan kegiatan wajib yang dilaksanakan oleh seluruh siswa. Hal tersebut dimaksudkan untuk menumbuhkan jiwa spiritual dan membentuk kebiasaan yang positif diantara siswa. Dalam kegiatan belajar mengajar SD Aisyiyah menggunakan kurikulum 2013 dan muatan lokal. Muatan lokal yang dipelajari lebih kepada penguatan agama islam seperti Kebudayaan Islam, Bahasa Arab, Tahsin dan Tahfidz. Sebagai referensinya atau sumber belajarnya SD Aisyiyah Kuningan menggunakan buku dari PP Muhammadiyah, hal inilah yangmembuat SD Aisyiyyah berbeda dengan SD yang lain yang ada di Kabupaten Kuningan.

SD Aisyiyah Kuningan memiliki program penguatan karakter yaitu The Nine Golden Habits. Dimana program ini diimplementasikan melalui kegiatan - kegiatan siswa, diantaranya seperti mengaji, shalat berjamaah, kepemimpinan, literasi. The Nine Golden Habits ini $75 \%$ sudah terlaksana. The Nine Golden Habits merupakan salah satu upaya mewujudkan cita - cita Muhammadiyah yakni menegakkan dan menjunjung tinggi Agama Islam sehingga terwujud masyarakat islam yang sebenar - benarnya. Selain itu program The Nine Golden Habits merupakan program penguatan nilai - nilai islami bagi seluruh civitas SD Aisyiyah Kuningan sehingga terwujud sekolah yang islami sesuai dengan tuntunan AlQur'an dan As-Sunnah. Kegiatan tambahan lainnya sebagai penguat dalam pembentukan karakter siswa yaitu Kegiatan Khitobah. Kegiatan ini merupakan kegiatan yang rutin dilakukan setiap Jum' at yang di dalamnya terdapat pembawa acara, yaang berpidato dan juga ceramah. Ini merupakan salah satu bentuk kegiatan penanaman karakter kepemimpinan dan tanggungjawab. Di akhir masa kegiatan belajar mengajar selalu dilaksanakan wisuda santri Juz 30.

Selain kegiatan pembiasaan tadi, ada beberapa kegiatan tambahan lain yang menjadikan SD Aisyiyah ini unggul dari SD yang lain yaitu Tahfidz, Tapak Suci dan Hizbul Wathan. Beberapa kegiatan yang dipaparkan tadi tidak terlepas dari peran serta guru dan kepala sekolah, dimana guru selalu memantau, memperhatikan juga bisa sebagai role model dan teladan bagi para siswa serta kepala sekolah sebagai supervisor.

\section{Nilai-nilai karakter dan keteladanan yang diimplementasikan pada siswa usia 6-8 tahun}

Sifat religius bisa dilihat dari kebiasaan dan keseharian peserta didik di SD Aisyiyah seperti berdoa sebelum dan setelah melaksanakan kegiatan contohnya berdoa sebelum dan sesudah belajar, melaksanakan ibadah di sekolah yaitu sholat duha dan sholat dzuhur yang dibiaskan setiap harinya sebelum melaksanakan pembelajaran siswa diarahkan untuk 
melaksanakan sholat duha berjamaah dimana salah satu siswa menjadi imam yang sudah di jadwalkan sehingga semua siswa laki-laki akan secara bergantian menjadi imam sesuai jadwal yang telah di tentukan, kegiatan ini selain menanamkan sifat religius bagi anak namun juga mengajarkan anak untuk memiliki sifat sebagai pemimpin dan bertanggung jawab. Siswa juga dibiasakan setelah sholat untuk mushafahah yaitu bersalam-salaman baik kepada guru maupun siswa kegiatan ini merupakan upaya yang dilakukan sekolah agar siswa memiliki sikap sopan santun, saling menghargai atau toleransi,

Selain itu juga siswa dibiasakan untuk menyisihkan uangnya untuk infaq, dimana setelah melaksanakan sholat duha siswa masuk ke kelasnya masing-masing sebelum melaksanakan pembelajaran siswa di arahkan untuk menyisihkan uang jajannya untuk di infaqkan kegiatan ini dimaksudkan agar siswa memiliki sifat peduli, ikhlas, menumbuhkan rasa empati. Sebelum proses pembelajaran berlangsung siswa melaksanakan tashin terlebih dahulu secara rutin sesuai dengan jilidnya, dimana siswa bukan hanya diajarkan mengaji saja namun juga diajarkan bacaan yang baik dan benar dimulai dari panjang pendek ayat, makhrojul huruf, tajwid dan yang lainnya.

Dalam penanaman sikap nasionalis sekolah memfasilitasi untuk memperingati harihari kebangsaan bermaksud agar siswa memiliki rasa cinta terhadap tanah air, bangga terhadap Negara Indonesia. Kemudian siswa di sekolah di biasakan untuk menggunakan bahasa indonesia yang baik, agar siswa bisa cinta dan bangga terhadap bahasa indonesia, siswa juga di arahkan untuk memiliki sikap toleransi dengan tidak membeda-bedakan teman, menghormati perbedaan yang ada dengan berbagai cara salah satunya ketika siswa diajak untuk berdiskusi, dalam pembelajaran diskusi siswa diharapkan untuk mendengarkan pendapat orang lain dengan baik, menghargai ketika ada perbedaan pendapat dan tidak saling menyalahkan. Di SD Aisiyah menanamkan karakter nasionalis melalui kegiatan bercerita mengenai sejarah tokoh Muhammadiyah, yaitu K.H. Ahmad Dahlan, SD Aisiyah selalu menanamkan karakter berdasarkan penokohan, karena K.H. Ahmad Dahlan memiliki rasa Nasionalisme yang kuat, salah satu contohnya Beliau mengajar di sekolahan Belanda yang dikelola oleh orang Belanda dan mengajar murid-murid dari dari keturunan orang Belanda dan kalangan priyayi. Beliau juga bersahabat dan berdialog dengan tokoh agama lain seperti Pastur van Lith pada 1914-1918. Van Lith adalah pastur pertama yang diajak dialog oleh Dahlan. Pastur van Lith di Muntilan yang merupakan tokoh di kalangan keagamaan Katolik. Pada saat itu Kiai Dahlan tidak ragu-ragu masuk gereja dengan pakaian hajinya (Sutarna \& Anwar, 2020), hal ini menunjukan sikap nasionalis yang kuat yang K.H Ahmad Dahlan miliki yang senantiasa di gunakan dalam penanaman karakter di SD Aisiyah Kabupaten Kuningan.

Penanaman karakter di SD Aisyiyah sangat di pentingkan sehingga antara kognitif, afektif dan psikomotorik itu seimbang, salah satunya dalam penanaman sikap jujur siswa di arahkan untuk menegur ketika ada teman yang menyontek, mengakui ketika belum mengerjakan tugas, curang dalam mengerjakan tugas, berbicara sesuai dengan fakta yang ada, mengakui ketika berbuat salah, menepati setiap janji, meminjam barang teman ketika di ijinkan, diharapkan pembiasaan berprilaku jujur ini agar dalam segala hal bentuk perbuatan siswa di dasari atas perbuatan jujur karena sudah di biasakan sejak sedini mungkin yang kedepannya sudah menjadi kebiasaan siswa dalam berprilaku. Penanaman karakter jujur melalui pembiasaan sehari-hari dalam menyelesaikan tugas dengan tepat waktu, berkata sesuai dengan kenyataan, tidak berbohong, penanamannya melalui kegiatan pengenalan sejarah mengenai tokoh Muhammadiyah K.H Ahmad Dahlan yang memilki karakter jujur(Sutarna \& Anwar, 2020).

Siswa di biasakan untuk mentaati setiap tata tertib yang ada, bisa dilihat dari peserta didik yang memakai seragam sesuai dengan jadwal, datang tepat waktu, menghargai pendapat dari teman, mendengarkan masukan dari guru mengerjakan tugas yang berikan oleh guru, tertib saat belajar, membuang sampah pada tempatnya, melaksanakan jadwal piket, menyimpan sepatu secara rapih pada tempatnya dimana kegiatan tersebut di biasakan 
agar siswa sudah terbiasa untuk mentaati setiap peraturan yang berlaku, sehingga kedepannya siswa akan mentaati peraturan yang ada di masyarakat, dan Negara Indonesia, menanmkan komitmen kepada siswa untuk belajar dengan giat baik di sekolah maupun di rumah kegiatan-kegiatan tersebut dilaksanakan dan diterapkan pada peserta didik sehingga peserta didik memiliki kepribadian yang baik sesuai dengan apa yang diharapkan.

\section{Pembahasan}

Berdasarkan hasil penelitian, maka kami menyimpulkan bahwa terdapat 4 karakter yang difokuskan untuk ditanamkan pada siswa di SD Aisiyah Kab. Kuningan.

\section{Nilai Karakter Religius}

Religius adalah sikap dan perilaku yang patuh dalam melaksanakan ajaran agama yang dianutnya, toleran terhadap pelaksanaan ibadah agama lain, serta 93 hidup rukun dengan pemeluk agama lain (Sutarna, 2018)

Karakter religius merupakan nilai-nilai kehidupan yang mencerminkan tumbuhkembangnya kehidupan beragama yang terdiri dari tiga unsur pokok yaitu aqidah, ibadah dan akhlak yang menjadi pedoman perilaku sesuai dengan aturan-aturan ilahi untuk mencapai kesejahteraan, hal ini ditunjukkan oleh siswa di SD Aisiyah dengan menunjukan sikap rutin melaksanakan doa sebelum dan setelah kegiatan pembelajaran, melaksanakan kegiatan sholat dzhuhur secara berjamaah dan sholat duha yang rutin dilaksanakan setiap pagi hari sebelum pembelajaran berlangsung. Selain itu juga siswa dibiasakan untuk menyisihkan uangnya untuk infaq, dimana setelah melaksanakan sholat duha siswa masuk ke kelasnya masing-masing sebelum melaksanakn pembelajaran siswa di arahkan untuk menyisihkan uang jajannya untuk di infaqkan kegiatan ini dimaksudkan agar siswa memiliki sifat peduli, ikhlas, menumbuhkan rasa empati. Sebelum proses pembelajaran berlangsung siswa melaksanakan tashin terlebih dahulu secara rutin sesuai dengan jilidnya, dimana siswa bukan hanya diajarkan mengaji saja namun juga diajarkan bacaan yang baik dan benar dimulai dari panjang pendek ayat, makhrojul huruf, tajwid dan yang lainnya.

Berdasarkan hasil penelitian (Churiyah et al., 2020)bahwa ada empat aspek karakter religius yang ditanamkan dalam keluarga yaitu keyakinan, amalan, sikap, dan pengetahuan. Dalam menerapkan karakter religius ada beberapa metode yang digunakan orang tua untuk menanamkan setiap aspek karakter religius (Trimuliana et al., 2019). Metode ceramah dan mendongeng untuk menanamkan aspek keyakinan, metode ceramah, dan praktik langsung dalam aspek sikap dan praktik. Metode bercerita dan dialog dalam menanamkan pengetahuan karakter religius pada anak usia dini. Hal ini juga dilakukan oleh SD Aisiyah Kabupaten Kuningan, yaitu mengimplementasikan kegiatan bercerita mengenai tokoh Muhammadiyah yaitu K.H Ahmad Dahlan yang memiliki karakter jujur, sehingga penanaman karakter jujur dapat dengan mudah diimplementasikan melalui keteladanan berdasarkan tokoh.

Berdasarkan hasil penelitian Yunita \& Anggraini (2020)) mendapatkan temuan bahwa bentuk upaya pembiasaan yang dilakukan oleh sekolah yaitu pembiasaan dalam akhlak, ibadah, dan keimanan. Berikut akan dijelaskan temuan-temuan di sekolah terkait dengan teori ini: (1) upaya pembiasaan dalam akhlak, upaya pembiasaan akhlak berupa pembiasaan dalam berbuat kebaikan, seperti selalu berperilaku jujur, datang ke sekolah tepat waktu, menghormati guru dan orang yang lebih tua, menyayangi teman, membantu siapa saja yang membutuhkan, (2) upaya pembiasaan dalam beribadah, upaya pembiasaan dalam hal ibadah seperti membiasakan membaca "bismillah" sebelum melakukan sesuatu, membaca "hamdalah" setiap melakukan sesuatu, wajib mengikuti sholat dzuhur di sekolah, dan sebagainya. (3) Upaya pembiasaan iman, upaya pembiasaan ini merupakan pembiasaan berupa membangun rasa keimanan dalam hati peserta didik dalam kegiatan sehari-hari. Hal ini juga dilakukan oleh siswa di SD Aisiyah, mereka terbiasa membaca bismilah ketika akan melakukan sesuatu. 


\section{Nilai Karakter Nasionalis}

Sikap karakter nasionalis juga teramati saat kegiatan rutin yang dilakukan yaitu terbiasa melaksanakan upacara bendera setiap hari senin, kemudian sekolah memfasilitasi untuk memperingati hari-hari kebangsaan bermaksud agar siswa memiliki rasa cinta terhadap tanah air, bangga terhadap Negara Indonesia. Kemudian siswa di sekolah di biasakan untuk menggunakan bahasa indonesia yang baik, agar siswa bisa cinta dan bangga terhadap bahasa indonesia, siswa juga di arahkan untuk memiliki sikap toleransi dengan tidak membeda-bedakan teman, menghormati perbedaan yang ada dengan berbagai cara salah satunya ketika siswa diajak untuk berdiskusi, dalam pembelajaran diskusi siswa diharapkan untuk mendengarkan pendapat orang lain dengan baik, menghargai ketika ada perbedaan pendapat dan tidak saling menyalahkan. Siswa di SD Aisiyah Kabupaten Kuningan terdiri dari beberapa daerah, sehingga memiliki beberapa bahasa daerah sesuai dengan ciri khas mereka, namun disini terlihat mereka terlihat saling menghargai walaupun penggunaan bahasa daerah yang berbeda ketika kegiatan bermain berlangsung, siswa dengan siswa lainnya saling berkomunikasi dengan menggunakan bahasa daerahnya masing-masing. Sekolah memfasilitasi kegiatan siswa yang menunjukan karakter nasionalis yaitu dengan memfasilitasi anak dalam memperingati hari-hari besar seperti memperingati hari kemerdekaan RI dengan mengadakan lomba-lomba, memperingati Milad Aisiyah dan Milad Muhammadiyah dengan mengadakan pengajian dan mengadakan lomba-lomba, memperkenalkan anak dengan lagu-lagu kebangsaan, mengenalkan nama presiden dan wakil presiden, mengenalkan keragaman budaya daerah dengan membiasakan anak menggunakan bahasa daerahnya sendiri ketika anak bermain, jadi penggunaan bahasa indonesia hanya digunakan ketika proses pembelajaran berlangsung, namun ketika anak berkomunikasi dengan temannya di SD Aisiyah annak dibiasakan agar menggunakan bahasa daerahnya sendiri. Hal ini bertujuan agar siswa mengenal dan mencintai negaranya sendiri, serta agar dapat mengenal mengenai organisasi Muhammadiyah dan Aisiyah. Berdasarkan hasil penelitian (Abu Bakar et al., 2018) bahwa karakter nasionalis dapat di tumbuhkan dengan memperkenalkan pada siswa budaya daerah setempat, sehingga siswa dapat mengenal keragaman budayanya sendiri.

\section{Nilai Karakter Jujur}

Siswa di SD Aisiyah mengimplementasikan karakter jujur dalam pembiasaan seharihari, seperti melakukan kegiatan sekolah sesuai yang diperintahkan guru, mengikuti kegiatan keagamaan sesuai perintah. Kejujuran KH Ahmad Dahlan dapat dilihat ketika masalah arah kiblat. Ketika masuk waktu shalat dhuhur, seorang muadzin Masjid Agung melihat ada tiga garis putih yang melintang di depan tempat imam dari arah utara ke selatan. Tiga buah garis sejajar dengan jarak selebar orang shalat berjamaah itu agak condong ke utara sekitar 23 derajat. Garis tersebut seolah-olah memberikan isyarat agar melaksanakan shalat berjamaah mengikuti garis tadi (Wibowo, 2017).

Jujur berarti apa yang dikatakan sesuai dengan perbuatan, karakter jujur ditanamkan pada siswa SD Aisiyah Kabupaten Kuningan yaitu melalui pembiasaan sehari-hari, guru di SD Aisiyah senantiasa menanamkan karakter jujur dalam pembiasaan sehari-hari. Berdasarkan hasil penelitian(M, Suud et al., 2020) menunjukkan bahwa kejujuran secara keseluruhan berdampak baik bagi kesehatan fisik dan kesehatan mental individu. Kejujuran terkait dengan banyak atribut psikologis. Oleh karena itu, disarankan untuk menanamkan motivasi dalam pendidikan kejujuran yang disimpulkan dari berbagai disiplin ilmu. Hasil penelitian (Haroswinarti et al., 2021) bahwa karakter jujur pada anak menjadikan anak lebih mandiri dan bertakwa, oleh karena itu pendidikan karakter pada anak perlu diperhatikan agar bangsa dan negara dapat maju.

Terlihat ketika dalam proses pembelajaran anak senantiasa bekerja bersungguhsungguh mengerjakan pekerjaannya sendiri sampai selesai tanpa menunggu orang lain atau tanpa terpengaruh oleh orang lain, kemudian anak di biasakan untuk melakukan kegiatan 
sholat duha, disini terlihat bahwa anak senantiasa melaksanakan kegiatan sholat duha tanpa intruksi lagi, dan anak yang belum melaksanakan sholat duha selalu melaksanakannya walaupun terlambat. Disini membuktikan bahwa anak berani berkomitmen dan telah jujur mengikuti kegiatan sholat duha walaupun terlambat, anak senantiasa menaati aturan yang telah diterapkan oleh sekolah dengan mengikuti kegiatan praktek sholat, kegiatan tahfiz maupun tahsin dengan tepat waktu. Karakter jujur senantiasa diterapkan melalui kegiatan bercakap-cakap dan tanya jawab mengenai karakter jujur, serta karakter jujur ditanamkan melalui contoh langsung atau modelling, guru senantiasa menjadi contoh yang baik bagi siswa nya sehingga siswa dapat meniru apa yang dilakukan guru, keteladanan merupakan salah satu hal yang penting dalam pendidikan. Pembiasaan dan keteladanan merupakan proses pendidikan yang berlangsung dengan membiasakan dan mencontohkan perilaku atau sosok figur dalam bertingkah laku, berbicara, berpikir dan melakukan aktivitas tertentu untuk membentuk kebiasaan yang baik sehingga akan membentuk karakter yang baik pula, keteladanan berarti hal yang dapat ditiru atau dicontoh(Budiyono \& Harmawati, 2020). Keteladanan adalah teknik dalam pendidikan yang paling baik. Seorang anak harus memperoleh teladan dari keluarga dan lingkungan sekitar. Dalam pendidikan, nasehat saja tidak cukup bila tidak disertai dengan keteladanan. Salah satu ciri-ciri orang yang berkarakter adalah setiap perkataan yang keluar dari mulutnya akan selalu selaras dengan perbuatan (Ahmad Dahlan, 1985) begitu pula yang ditanamkan oleh K.H Ahmad Dahlan bahwa harus senantiasa memiliki karakter atau tingkah laku yang sesuai dengan ucapan.

\section{Nilai Karakter Integritas}

Pandangan KH Ahmad Dahlan, agama Islam tidak bisa tegak tanpa diperjuangkan melalui sebuah wadah (organisasi) profesional. Demikian pula untuk membebaskan bangsa Indonesia dari penjajahan Belanda, harus dengan meningkatkan ilmu pengetahuan dan lembaga pendidikan. (Sucipto, 2010).

Pada sekolah SD Aisiyah juga menanamkan karakter integritas, dimana siswa di biasakan untuk mentaati setiap tata tertib yang ada, bisa dilihat dari peserta didik yang memakai seragam sesuai dengan jadwal, datang tepat waktu, menghargai pendapat dari teman, mendengarkan masukan dari guru mengerjakan tugas yang berikan oleh guru, tertib saat belajar, membuang sampah pada tempatnya, melaksanakan jadwal piket, menyimpan sepatu secara rapi pada tempatnya dimana kegiatan tersebut di biasakan agar siswa sudah terbiasa untuk mentaati setiap peraturan yang berlaku, sehingga kedepannya siswa akan mentaati peraturan yang ada di masyarakat, dan Negara Indonesia, menanamkan komitmen kepada siswa untuk belajar dengan giat baik di sekolah maupun di rumah kegiatan-kegiatan tersebut dilaksanakan dan diterapkan. Siswa di SD Aisiyah sudah terbiasa menerapkan karakter integritas dengan memberikan aturan pada anak secara konsisten, aturan yang diterapkan adalah Sholat duha dilaksanakan pada pukul 07.30 sebelum pembelajaran dimulai. Imam dipilih secara bergantian setiap harinya yang diambil dari siswa dan dibimbing oleh guru, dimana guru membenarkan posisi shalat ketika ada posisi gerakan siswa yang salah. Setelah shalat dhuha, siswa bermusyafahah dengan sesama teman dan guru secara tertib.

Pukul 08.00 sampai 09.10 kegiatan tahsin, tahsin dilaksanakan sebelum pembelajaran dimulai. Siswa dikelompokkan sesuai dengan jilid atau kemampuan siswa dalam mengaji. Tahsin ini diawali dengan tes mengaji siswa satu persatu secara acak. Kemudian dibaca secara bersamaan dan siswa maju satu persatu untuk di tes. Ada beberapa kriteria penilaian yang nantinya menjadi tolak ukur bisa tidaknya siswa tersebut melanjutkan ke halaman selanjutnya. Kemudian setelah kegiatan tahsin adalah kegiatan belajar mengajar yang dilaksanakan di sekolah dengan memenuhi standar protokol kesehatan, kemudian kegiatan istirahat dilaksanakan pada pukul 10.20 sampai 10.40 setelah itu melanjutkan kegiatan belajar mengajar sampai pukul 12.00 dan kegiatan sholat dzuhur secara berjamaah, dan setelah sholat dzuhur siswa melaksanakan kegiatan KBM sampai pukul 13. 00. Disini terlihat siswa pulang secara bergantian, mengambil sepatunya dan pulang dengan tertib tanpa berdesakan. Jumlah 
siswa yang tidak terlalu banyak sehingga siswa dengan mudah dapat mengikuti aturan atau tata tertib sekolah.

Penanaman karakter dan keteladanan berdasarkan hasil penelitian dari (Jannah \& Ahmad, 2019) bahwa penanaman keteladanan itu melalui pengenalan tokoh yaitu K.H. Ahmad Dahlan sebagai tokoh Muhammadiyah yang dapat diteladani, kemudian melalui contoh secara langsung yaitu implementasi bisa diterapkan oleh guru tersebut kemudian diimplementasikan pada siswa. Hal ini senantiasa diterapkan di SD Aisiyah Kabupaten kuningan, yaitu melalui kegiatan bercerita mengenai kisah K.H. Ahmad Dahlan dapat menanamkan karakter dan keteladanan siswa. Keterbatasan penelitian ini adalah karakter yang ditanamkan oleh K.H. Ahmad Dahlan hanya dilakukan di sekolah lingkungan Muhammadiyah atau AUM (Amal Usaha Muhammadiyah), tidak ditanamkan pada sekolah umum.

\section{SIMPULAN}

Berdasarkan hasil penelitian maka dapat disimpulkan bahwa terdapat 4 nilai karakter dan keteladanan yang terdapat pada anak usia 6-8 di SD Aisiyah Kabupaten Kuningan, SD Aisyiyah Kuningan khususnya pada anak usia 6-8 tahun, memiliki program penguatan karakter yaitu The Nine Golden Habits. Dimana program ini diimplementasikan melalui kegiatan-kegiatan siswa, diantaranya seperti mengaji, shalat berjamaah, kepemimpinan, literasi. The Nine Golden Habits merupakan salah satu upaya mewujudkan cita-cita Muhammadiyah yakni menegakkan dan menjunjung tinggi Agama Islam sehingga terwujud masyarakat islam yang sebenar-benarnya. Implementasi pendidikan karakter pada siswa SD Aisiyah berdasarkan nilai pendidikan Karakter dan keteladanan K.H. Ahmad Dahlan diantaranya yaitu, religius, jujur, nasionalis dan integritas, pendidikan karakter K.H. Ahmad Dahlan dapat mendukung pendidikan karakter Kemendikbud sehingga mampu menciptakan pendidikan karakter yang efektif.

\section{UCAPAN TERIMA KASIH}

Ucapan Terima Kasih disampaikan kepada Majelis Pendidikan Tinggi Penelitian dan Pengembangan Pimpinan Pusat Muhammadiyah yang telah memberikan Hibah Riset Muhammadiyah 2021, sehingga mendukung terlaksananya penyusunan karya tulis ilmiah ini. Terimakasih pula pada segenap unsur pimpinan STKIP Muhammadiyah Kuningan sebagai tempat penulis bernaung, dan tak lupa terima kasih juga disampaikan kepada para pihak yang telah membantu penulisan karya tulis ilmiah ini, reviewer serta editor jurnal, sehingga penulis dapat mempublikasikan topik ini..

\section{DAFTAR PUSTAKA}

Abu Bakar, K. A., Noor, I. H. M., \& Dan Widodo. (2018). Nurturing nationalism character valuesat the primary schools in jayapura, papua. Cakrawala Pendidikan, 37(1), 42-56. https://doi.org/10.21831/cp.v37i1.13616

Ahmad Dahlan. (1985). Tali Pengikat Hidup Manusia, Dalam Buku Perkembangan Pemikiran Muhammadiyah Dan Masa ke Masa, Menyambut Muktamar Ke-41. PT Dua Dimensi.

Albert, B. (1977). Social Learning Theory. Prentice-Hall, Inc.

Apriliyanti, F., Hanurawan, F., \& Sobri, A. Y. (2021). Keterlibatan Orang Tua dalam Penerapan Nilai-nilai Luhur Pendidikan Karakter Ki Hadjar Dewantara. Jurnal Obsesi : Jurnal Pendidikan Anak Usia Dini, 6(1), 1-8. https://doi.org/10.31004/obsesi.v6i1.595

Budiyono, \& Harmawati, Y. (2020). Penguatan Pendidikan Karakter Melalui Nilai-Nilai Keteladanan Guru Dan Orang Tua Pada Siswa Sekolah Dasar. Prosiding Seminar Nasional PPKn III, 1-10.

Churiyah, M., Sholikhan, S., Filianti, F., \& Sakdiyyah, D. A. (2020). Indonesia Education Readiness Conducting Distance Learning in Covid-19 Pandemic Situation. 
International Journal of Multicultural and Multireligious Understanding, 7(6), 491. https://doi.org/10.18415/ijmmu.v7i6.1833

Creswell, J. W. (2010). Research Design: Pendekatan Kualitatif, Kuantitatif, dan Mixed. Pustaka Pelajar.

Haerudin, D. A. . N. C. (2018). Penerapan Metode Storytelling Berbasis Cerita Rakyat Dalam Menanamkan Nilai-Nilai Karakter Anak. Jurnal Pelita PAUD, 3(1), 1-9. https:// doi.org/10.33222/pelitapaud.v3i1.420

Haroswinarti, K., Sasongko, R. N., Kristiawan, M., \& Mentari, E. G. (2021). A Case Study of Honest Character Development in Early Childhood in Bengkulu City. Al-Athfaal: Jurnal Ilmiah Pendidikan Anak Usia Dini, 4(1), 124-136. https://doi.org/10.24042/ajipaud.v4i1.8607

HM Masrudin Anshory. (2010). Matahari Pembaharuan Rekam Jejak KH. Ahmad Dahlan. Galangpress.

Jannah, U. A., \& Ahmad, T. A. (2019). Kesadaran Sejarah Siswa Kelas Xi Terhadap Nilai-Nilai Keteladanan K.H Ahmad Dahlan Di Sma Muhammadiyah 1 Semarang. Indonesian Journal of History Education, 7(2), 135-145. https://doi.org/10.15294/ijhe.v7i2.36430

Kumalasari, D. (2017). Pendidikan Karakter dalam Perspektif Tokoh Muhammadiyyah. I(1), 5-12. https:// doi.org/10.17509/historia.v1i1.8603

M, Suud, F., Sutrisno, \& Abd.Madjid. (2020). Honesty: A Multidimensional Study as Motivation for National Character Building. Hayula: Indonesian Journal of Multidisciplinary Islamic Studies, 4(1), 99-116. https:// doi.org/10.21009/004.01.06

Mulkhan, A. M. (2016). Pemikiran KH Ahmad Dahlan dan Muhammadiyah. Bumi Aksara.

Prasanti, D., \& Fitrianti, D. R. (2018). Pembentukan Karakter Anak Usia Dini: Keluarga, Sekolah, Dan Komunitas. Pembentukan Anak Usia Dini: Keluarga, Sekolah, Dan Komunitas, 2(1), 15. https://doi.org/10.31004/obsesi.v2i1.2

Puspitasari, E. (2014). Pendekatan pendidikan karakter. Jurnal Golden Age, 3(1), 9-17.

Sucipto, H. (2010). KH. Ahmad Dahlan: Sang Pencerah, Pendidikan, dan Pendiri Muhammadiyah. Best Media Utama.

Sutarna, N. (2018). Pendidikan Karakter Siswa Sekolah Dasar dalam Perspektif Islam. Pustaka Diniah.

Sutarna, N., \& Anwar, A. S. (2020). Value of Character and Philosophy of Life KH. Ahmad $\begin{array}{llll}\text { Dahlan. Istawa: Jurnal Pendidikan Islam, } 206 . & \end{array}$ https:// doi.org/10.24269/ijpi.v5i2.2558

Trimuliana, I., Dhieni, N., \& Hapidin, H. (2019). Perilaku Religius Anak Usia 5-6 Tahun pada PAUD Model Karakter. Jurnal Obsesi : Jurnal Pendidikan Anak Usia Dini, 3(2), 570. https:// doi.org/10.31004/obsesi.v3i2.251

Wibowo, S. S. S. (2017). Pendidikan Karakter dalam Pembelajaran Al-Islam, Kemuhammadiyahan, dan Bahasa Arab. Pustaka Pelajar.

Wiranata, R. S. (2019). Rz. Ricky Satria Wiranata. 2(20), 101-146.

Yunita, G. F. R., \& Anggraini, P. (2020). Comparative Study of Nasionalism Main Characters in The Novel Negeri van Oranje and Diary Buruh Migran. AKSIS: Jurnal Pendidikan Bahasa dan Sastra Indonesia, 230-251. http://journal.unj.ac.id/unj/index.php/aksis/article/view/17070 